\title{
ROLE OF HETEROCYCLIC DYE (METHYLENE BLUE) WITH REDUCTANT AND MICELLES IN PHOTOGALVANIC CELL FOR SOLAR ENERGY CONVERSION AND STORAGE
}

\author{
A.S. Meena ${ }^{1}$, Rishikesh ${ }^{2}$, R.C. Meena ${ }^{3}$ \\ ${ }^{I}$ Department of Chemistry, MLS University, Udaipur-313001, Rajasthan (INDIA) \\ ${ }^{2,3}$ Department of Chemistry, JNV University, Jodhpur-342005, Rajasthan (INDIA) \\ anoopsingh10786@gmail.com, rishim2012@gmail.com,rcmeena007@rediffmail.com
}

\begin{abstract}
Studies of heterocyclic dye (Methylene blue) with reductant and micelles in photogalvanic cell containing Methylene blue-EDTA-TX100 system for solar energy conversion and storage The photopotential and photocurrent of the cell is observed $845.0 \mathrm{mV}$ and 420.0 $\mu A$ respectively. The conversion efficiency and fill factor of the cell are determined $1.08 \%$ and 0.2488 respectively. The storage capacity (performance) of the cell is observed 160.0 minutes in dark. The effects of different parameters on the electrical output of the cell were observed and current-voltage $(i-V)$ characteristics of the cell were also studied. The mechanism is proposed for the generation of photocurrent in photogalvanic cell.
\end{abstract}

Keywords: - Photogalvanic effect1, conversion efficiency2, storage capacity3, fill factor4. ***

\section{INTRODUCTION}

The solar energy is the most readily available nonconventional source of energy which is most abundantly and freely available renewable source of energy. The new approach for renewable energy sources has led to an increasing interest in photogalvanic cells because of their reliable solar energy conversion and storage capacity. Photogalvanic cells are a photoelectrochemical device in which solar energy convert into electrical energy via formation of energy rich species that exhibit the photogalvanic effect. The photogalvanic effect was first of all recognized by Rideal and Williams [1] and it was systematically studied by Rabinowitch [2-3], and then by other workers [4-9]. Some researchers [10-11] have studied on how to enhance the performance and optimum efficiency of dye sensitized solar cell for solar energy conversion. A detailed of literature survey reveals that photogalvanic cell consisting of various dyes with reductant, mixed dyes with reductant and dye with reductant and surfactant for solar energy conversion and storage reported time to time [12-26]. Recently some photogalvanic cells are developed by Meena and his co-workers [27-29] for generation of electrical energy from various photosensitiser and reductant. Present work is the effort to observe the role of hetrocyclic dye (Methylene blue) with reductant and micelles in photogalvanic cell for solar energy conversion and storage.

\section{EXPERIMENTAL METHODS}

Methylene blue (RANKEM), TX 100 (LOBA), EDTA (MERCK) and $\mathrm{NaOH}$ (MERCK) are used in the present work.
All the solutions are prepared in doubly distilled water and the stock solutions of all chemicals are prepared by direct weighing and are kept in coloured container to protect them from the light. The whole cell is set systematically for photogalvanic studies, which consists of thin foil of electrochemically treated platinum as electrode and the saturated calomel electrodes as a reference electrode. The distance between the illuminated and dark electrode is $45 \mathrm{~mm}$. An ordinary tungsten lamp of $200 \mathrm{~W}$ is used as light source. Water filter is used to cut-off IR radiations. The photopotetial is obtained as the difference between the initial potential of the cell in dark and the equilibrium potential attained by the cell under constant illumination. The potential is first measured in dark and the change in potential on illumination is measured as a function of time. The solution is bubbled with prepurified nitrogen gas for nearly twenty minutes to remove dissolved oxygen. Solutions of dye, reductant, micelles and sodium hydroxide are taken in an H-type glass tube. A platinum electrode $(1.0 \times 1.0 \mathrm{~cm} 2)$ is immersed into one arm of H-tube and a saturated calomel electrode (SCE) is kept in the other. The whole cell is first placed in dark till a stable potential is obtained and then, the arm containing the SCE is kept in the dark and the platinum electrode is exposed to a $200 \mathrm{~W}$ tungsten lamp. A water-filter is used to cut off infrared radiations. The photochemical bleaching of Methylene blue is studied potentiometrically. A digital $\mathrm{pH}$ meter (Systronics Model-335) and a microammeter (Ruttonsha Simpson) are used to measure the potential and current generated by the cell, respectively. The current-voltage characteristics of photogalvanic cell have been studied by applying an external 
load with the help of a carbon pot $(\log 470 \mathrm{~K})$ connected in the circuit through a key to have close circuit and open circuit device. The experimental set-up of photogalvanic cell is given in Figure-1. The effect of variation of different parameters has also been observed. The rate of change in potential after removing the source of illumination is $0.93 \mathrm{mVmin}-1$ in Methylene blue-EDTA-TX-100 cell.

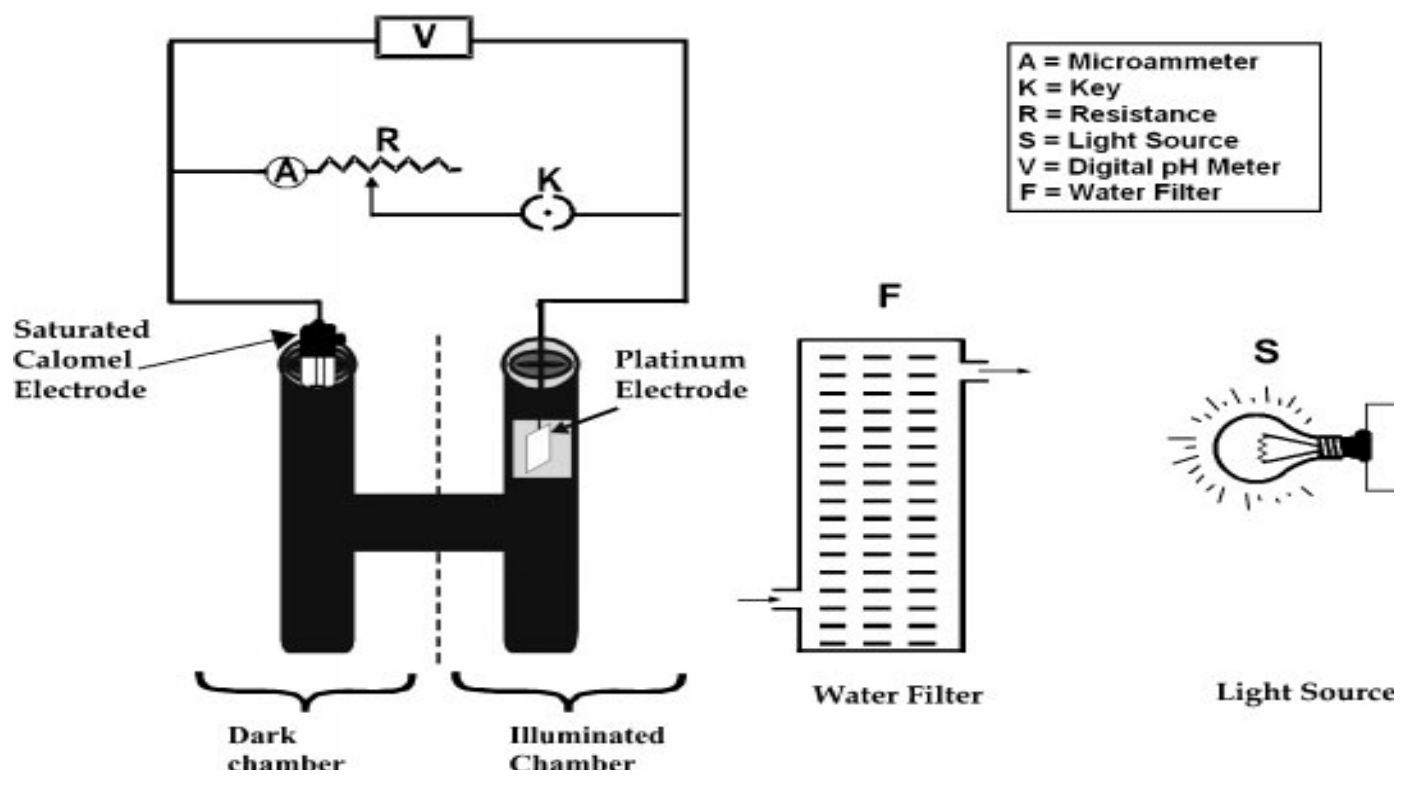

Fig-1 Experimental set-up of photogalvanic cell

\section{RESULTS AND DISCUSSION}

\subsection{Effect of Variation in Dye, Reductant and Micelles Concentration on the Cell}

The effect of variation in photosensitizer, reductant and micelles concentration on photoelectric parameters is studied. It is observed that the photopotential and photocurrent are increasing with respect to the concentration of the photosensitizer, reductant and micelles. A maximum is obtained for a particular value of photosensitizer (Methylene blue) concentration, reductant (EDTA) concentration and micelles (TX 100) concentration. On further increase in concentration of photosensitizer (Methylene blue), reductant (EDTA) and micelles (TX 100), a decrease in the electrical output of the cell is obtained.

The reason of the change in electrical output is that lower concentration of photosensitizer resulted into a fall in electrical output because fewer photosensitizer (Methylene blue) molecules are available for the excitation and consecutive donation of the electrons to the platinum electrode whereas the higher concentration of photosensitizer (Methylene blue) again resulted into a decrease into electrical output as the intensity of light reaching the dye molecules near the electrode decrease due to absorption of the major portion of the light by dye molecules present in the path.
The reason of the change in electrical output is that the lower concentration of reducing agent resulted into a fall in electrical output because fewer reducing agent molecules are available for electron donation to photosensitizer (Methylene blue) molecule whereas the higher concentration of reducing agent again resulted into a decrease in electrical output, because the large number of reducing agent molecules hinders the dye molecules from reaching the electrode in the desired time limit.

The reason of the change in electrical output is that the micelles solubilize the dye molecules up to highest extent at or around their micelle concentration. The above variations are reported in Table 1.

\subsection{Effect of Variation of $\mathrm{pH}$ on the Cell}

The effect of variation in $\mathrm{pH}$ on photoelectric parameters of cell is studied. It is found that the cell containing Methylene blue-EDTA-TX-100 to be quite sensitive to the $\mathrm{pH}$ of the solution. It is observed that there is an increase in the photoelectric parameters of this cell with the $\mathrm{pH}$ value (In the alkaline range). At $\mathrm{pH} 11.60$ a maxima is obtained. On further increase in $\mathrm{pH}$, there is a decrease in photoelectric parameters. It is observed that the $\mathrm{pH}$ for the optimum condition has a relation with $\mathrm{pKa}$ of the reductant and the desired $\mathrm{pH}$ is higher than in $\mathrm{pKa}$ value $(\mathrm{pH}>\mathrm{pKa})$. The reason of the change in 
electrical output is that the availability of the reductant in its presented in Table 1. anionic form, which is a better donor form. The above same is

Table-1Effect of concentration (Methylene blue, EDTA and TX 100) and pH on the cell

\begin{tabular}{|c|c|c|c|}
\hline Parameters & Photopotential (mV) & Photocurrent $(\boldsymbol{\mu} \mathbf{A})$ & Power $(\mu \mathbf{W})$ \\
\hline \multicolumn{4}{|c|}{ (Methylene blue $) \times 10^{-5} \mathrm{M}$} \\
\hline 1.98 & 732.0 & 322.0 & 235.70 \\
\hline 2.01 & 796.0 & 388.0 & 308.85 \\
\hline 2.04 & 845.0 & 420.0 & 354.90 \\
\hline 2.08 & 785.0 & 376.0 & 295.16 \\
\hline 2.11 & 712.0 & 312.0 & 222.14 \\
\hline \multicolumn{4}{|c|}{$\left(\right.$ EDTA) $\times 10^{-3} \mathbf{M}$} \\
\hline 1.10 & 766.0 & 342.0 & 261.97 \\
\hline 1.15 & 805.0 & 388.0 & 312.34 \\
\hline 1.20 & 845.0 & 420.0 & 354.34 \\
\hline 1.24 & 798.0 & 375.0 & 299.25 \\
\hline 1.29 & 712.0 & 318.0 & 226.42 \\
\hline \multicolumn{4}{|c|}{$($ TX 100$) \times 10^{-3} \mathrm{M}$} \\
\hline 0.79 & 756.0 & 315.0 & 238.14 \\
\hline 0.81 & 812.0 & 376.0 & 305.31 \\
\hline 0.84 & 845.0 & 420.0 & 354.90 \\
\hline 0.86 & 788.0 & 368.0 & 289.98 \\
\hline 0.88 & 712.0 & 302.0 & 215.02 \\
\hline \multicolumn{4}{|c|}{ pH } \\
\hline 11.48 & 742.0 & 332.0 & 246.34 \\
\hline 11.54 & 798.0 & 382.0 & 304.84 \\
\hline 11.60 & 845.0 & 420.0 & 354.90 \\
\hline 11.66 & 782.0 & 379.0 & 290.12 \\
\hline 11.72 & 714.0 & 322.0 & 229.91 \\
\hline
\end{tabular}

\subsection{Effect of Diffusion Length and Electrode Area on the Cell}

The effect of variation in diffusion length (distance between the two electrodes) on the photoelectric parameters of the cell $\left(i_{\max }, i_{\text {eq }}\right.$ and initial rate of generation of photocurrent) is studied using $\mathrm{H}$-shaped cells of different dimensions. The effect of electrode area on the photoelectric parameters of the cell is also reported here. It is observed that both $i_{\max }$ and rate of change in initial generation of photocurrent $\left(\mu \mathrm{A} \min ^{-1}\right)$ increase with respect to the diffusion length whenever the equilibrium photocurrent $\left(\mathrm{i}_{\mathrm{eq}}\right)$ shows a small decrease with respect to the diffusion length. The reason of the change in electrical output is that the main electroactive species are the leuco or semi-leuco form of dye (photosensitizer) and the dye in illuminated and dark chamber respectively. The reductant and its oxidation product act only as electron carriers in the path. The rate of change in photoelectric parameters with respect to the diffusion length is graphically presented in Table 2. Similarly, Table 3 shows rate of change in photoelectric parameter with respect to electrode area. It is found that the maximum photocurrent show increasing fashion with electrode area whereas the equilibrium photocurrent $\left(\mathrm{i}_{\mathrm{eq}}\right)$ show decreasing fashion.

Table-2 Effect of diffusion length

\begin{tabular}{|c|c|c|c|}
\hline $\begin{array}{c}\text { Diffusion Length } \\
\mathbf{D}_{\mathbf{L}}(\mathbf{m m})\end{array}$ & $\begin{array}{c}\text { Maximum photocurrent } \\
\mathbf{i}_{\mathbf{m a x}}(\boldsymbol{\mu} \mathbf{A})\end{array}$ & $\begin{array}{c}\text { Equilibrium photocurrent } \\
\mathbf{i}_{\mathbf{e q}}(\boldsymbol{\mu} \mathbf{A})\end{array}$ & $\begin{array}{c}\text { Rate of initial generation of } \\
\text { photocurrent }\left(\boldsymbol{\mu} \mathbf{A} \mathbf{~ m i n}^{-1}\right)\end{array}$ \\
\hline 35.0 & 478.0 & 428.0 & 13.28 \\
\hline 40.0 & 484.0 & 424.0 & 13.44 \\
\hline 45.0 & 490.0 & 420.0 & 13.61 \\
\hline 50.0 & 496.0 & 416.0 & 13.78 \\
\hline 55.0 & 502.0 & 412.0 & 13.94 \\
\hline
\end{tabular}


Table-3 Effect of electrode area

\begin{tabular}{|l|c|c|c|c|c|}
\hline \multicolumn{2}{|c|}{ Methylene blue-EDTA-TX 100 } & \multicolumn{5}{|c|}{ Electrode area $\left(\mathbf{c m}^{2}\right)$} \\
\cline { 2 - 7 } & $\mathbf{0 . 7 0}$ & $\mathbf{0 . 8 5}$ & $\mathbf{1 . 0 0}$ & $\mathbf{1 . 1 5}$ & $\mathbf{1 . 3 0}$ \\
\hline Maximum photocurrent $I_{\max }(\boldsymbol{\mu A})$ & 476.0 & 485.0 & 490.0 & 496.0 & 502.0 \\
\hline Equilibrium photocurrent $\mathbf{i}_{\text {eq }}(\boldsymbol{\mu A})$ & 434.0 & 426.0 & 420.0 & 412.0 & 406.0 \\
\hline
\end{tabular}

\subsection{Effect of Temperature and Light Intensity on the}

Cell

The effect of temperature on the photoelectric parameters of the cell is studied. The effect of light intensity on the photoelectric parameters of the cell also investigated here. It is observed that the photocurrent of the photogalvanic cell is found to be increased with the temperature whereas the photopotential is decreased. Thereafter, the effect of temperature on total possible power output in the Methylene blue-EDTA-TX 100 cell is also studied and it is observed that there a linear change between the both. The reason of the change in electrical output is that internal resistant of the cell decreases at higher temperature resulting into a rise in photocurrent and correspondingly, there will be a fall in photopotential. The same is presented in Figure 2. Similarly, Figure 3 shows rate of change in photoelectric parameter with respect to light intensity. The light intensity is measured in terms of $\mathrm{mWcm}^{-2}$ with the help of solarimeter (CEL Model SM 203). It is found that the photocurrent show linear increasing fashion with light intensity whereas the photopotential show an increment in a logarithmic fashion.

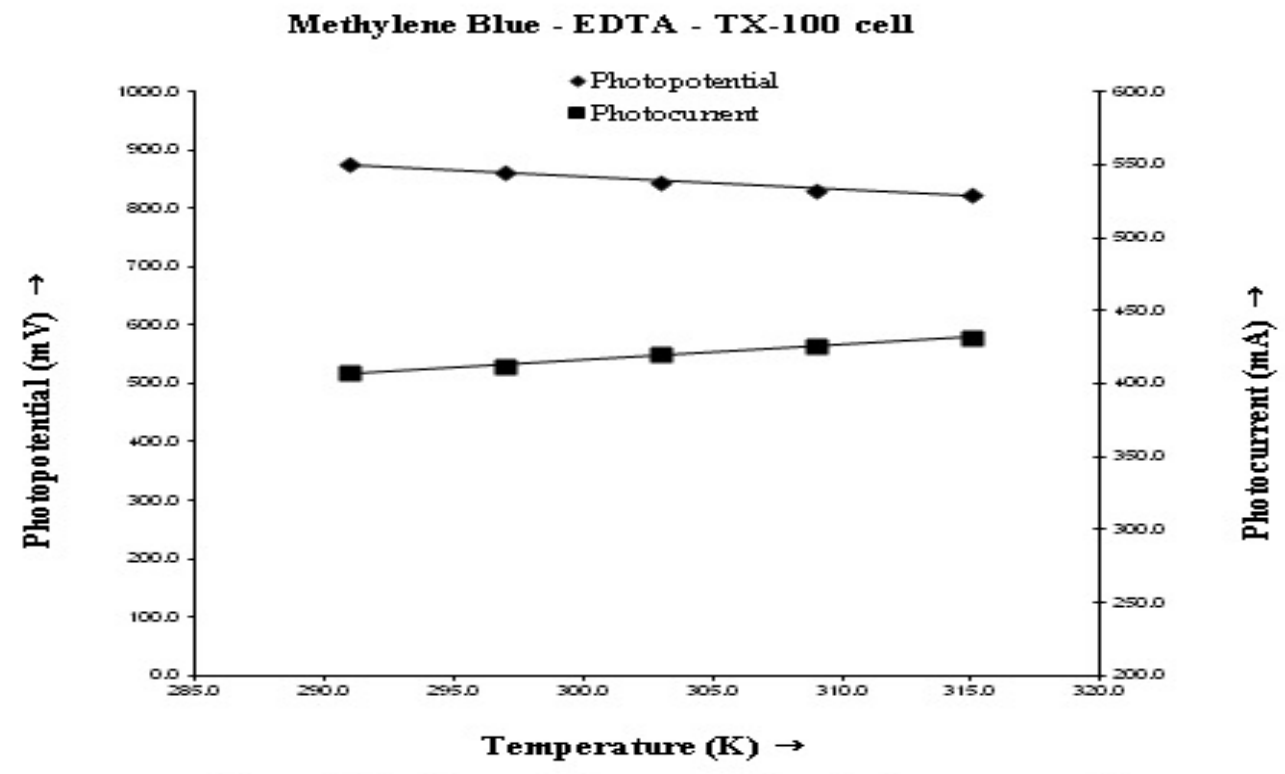

Figure-2 $\mathrm{V}$ ariation of photopotential and photocurrent with tem perature 


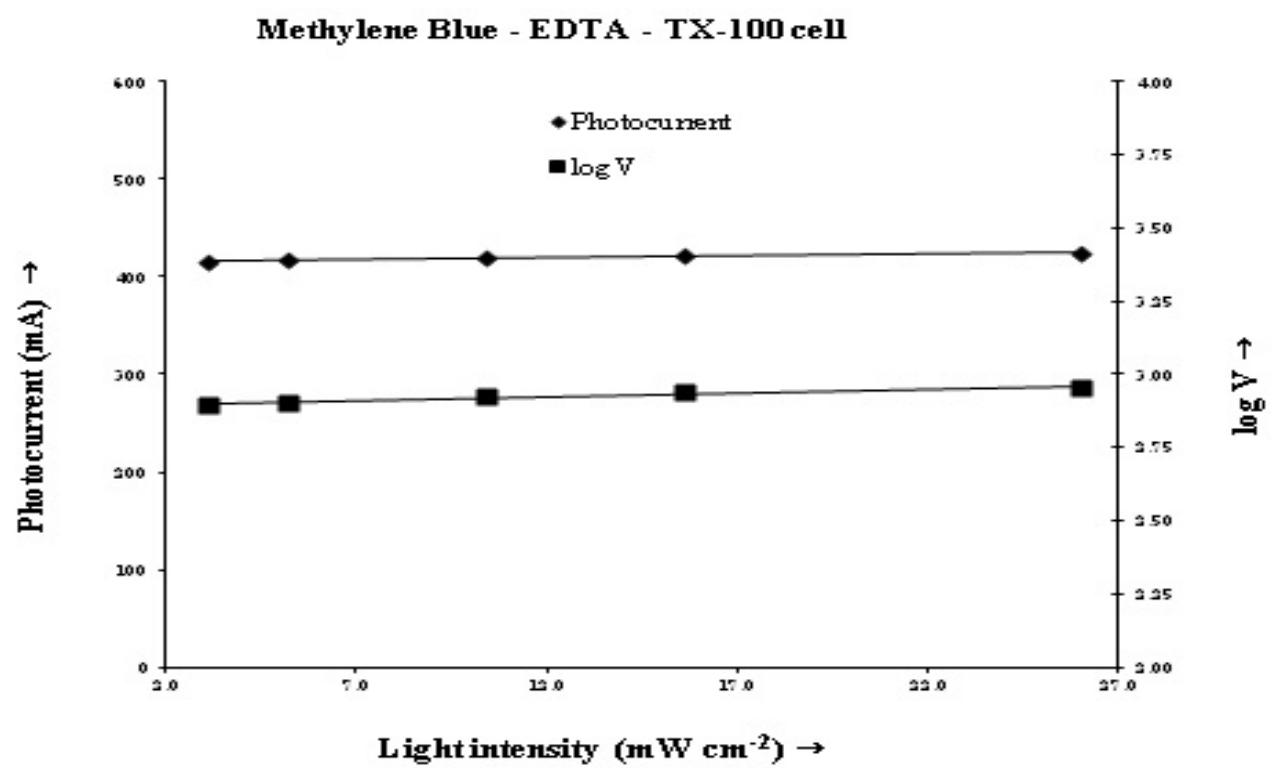

Figure-3 $\mathrm{V}$ ariation of photocurrent and $\log \mathrm{V}$ with light intensity

\subsection{Current-Voltage (i-V) Characteristics of the Cell}

The short circuit current $\left(\mathrm{i}_{\mathrm{sc}}\right)$ and open circuit voltage $\left(\mathrm{V}_{\mathrm{oc}}\right)$ of the photogalvanic cells are measured with the help of a multimeter (keeping the circuit closed) and with a digital $\mathrm{pH}$ meter (keeping the other circuit open), respectively. The current and potential values in between these two extreme values are recorded with the help of a carbon pot $(\log 470 \mathrm{~K})$ connected in the circuit of Multimeter, through which an external load is applied. The current-voltage (i-V) characteristics of the photogalvanic cells containing Methylene blue-EDTA-TX-100 cell is graphically shown in Figure 4.

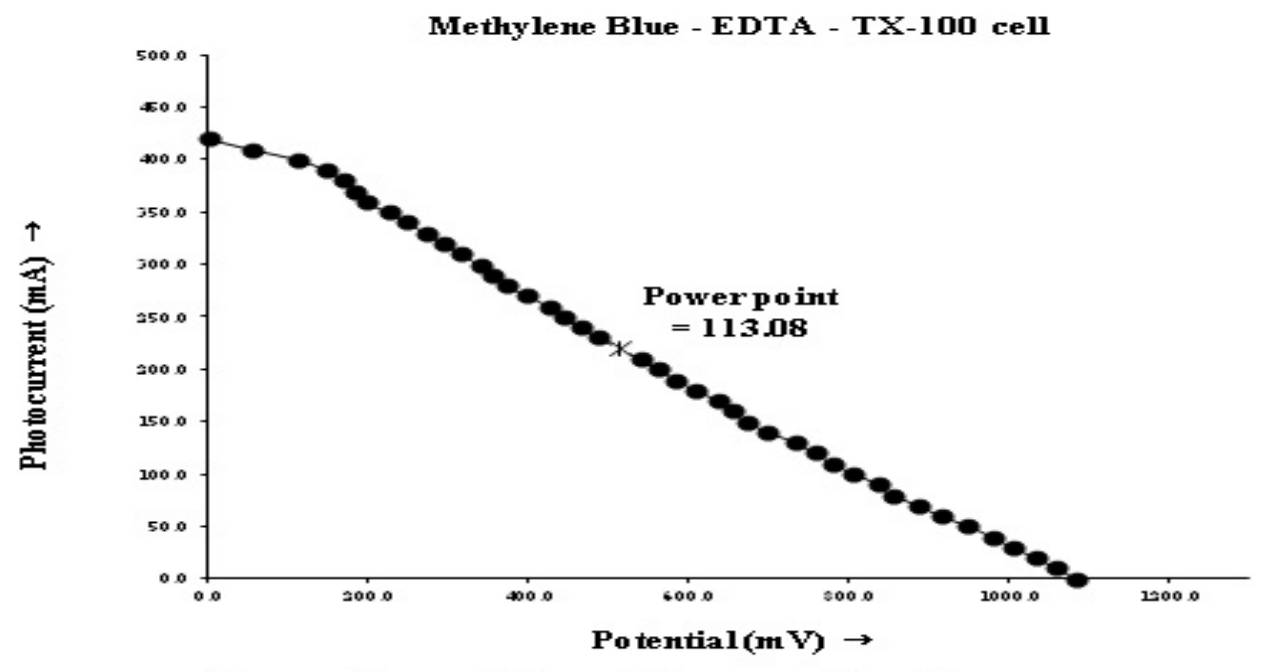

Figure-4 Current-V oltage (i-V) curve of the cell 


\subsection{Storage Capacity (Performance) and Conversion Efficiency of the Cell}

The storage capacity (performance) of the photogalvanic cell is observed by applying an external load (necessary to have current at power point) after terminating the illumination as soon as the potential reaches a constant value. The storage capacity (performance) is determined in terms of $t_{1 / 2}$, i.e., the time required in the fall of the output (power) to its half at power point in dark. It is observed that the cell can be used in dark for 160.0 minutes, on irradiation for 130.0 minutes. So the observed storage capacity (Performance) of the cell is $123.07 \%$. The results are graphically presented in Figure 5. The conversion of the efficiency of the cell is determined as $1.087 \%$ with the help of photocurrent and photopotential values at the power point and the incident power of radiations by using the formula

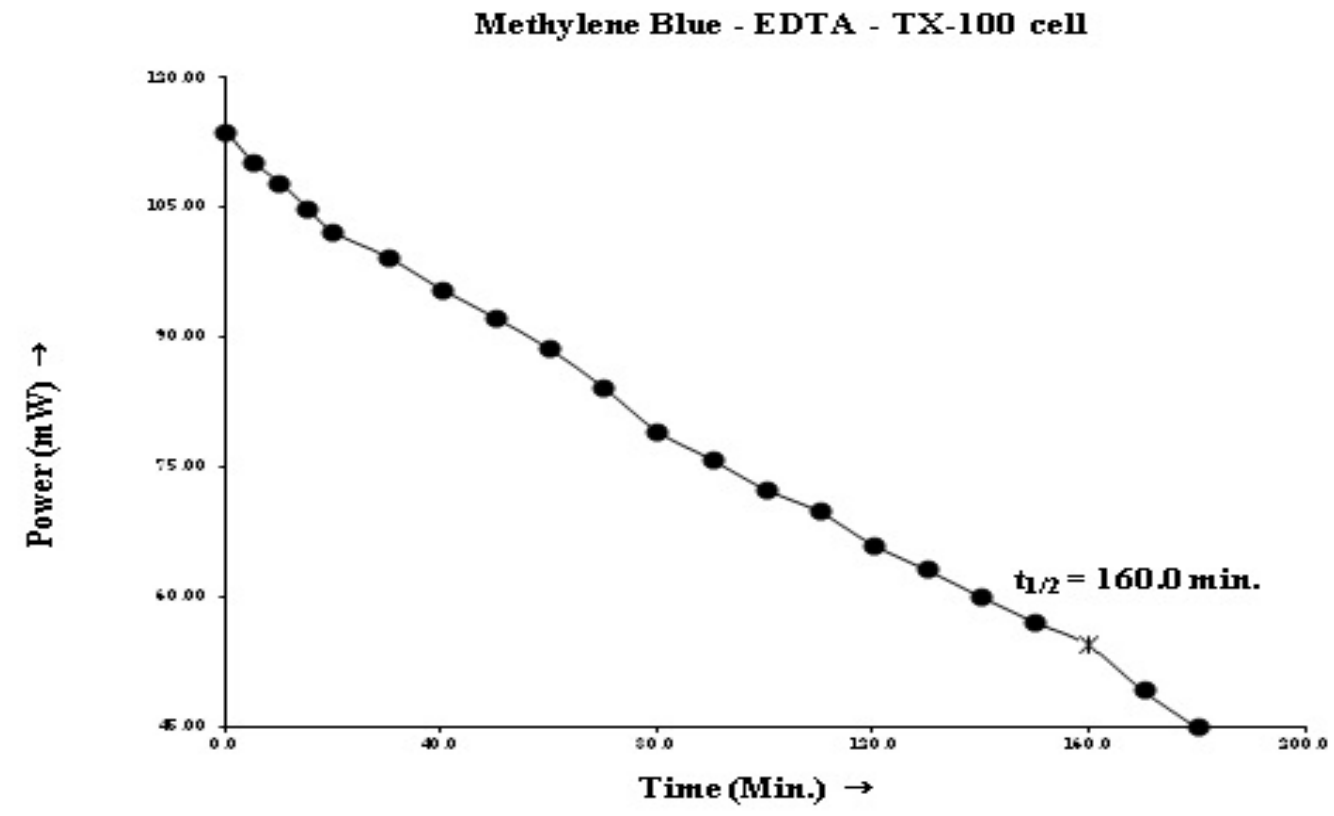

Figure-5 Perform ance of the cell

Fill factor $(\eta)=\frac{\mathrm{V}_{\mathrm{pp}} \times \mathrm{i}_{\mathrm{pp}}}{\mathrm{V}_{\mathrm{oc}} \times \mathrm{i}_{\mathrm{sc}}}$

Conversion Efficiency $=\frac{\mathrm{V}_{\mathrm{pp}} \times \mathrm{i}_{\mathrm{pp}}}{10.4 \mathrm{~mW} \mathrm{~cm}^{-2}} \times 100 \%$

\section{MECHANISM}

On the basis of these observations, a mechanism is suggested for the generation of photocurrent in the photogalvanic cell as:

\subsection{Illuminated Chamber}

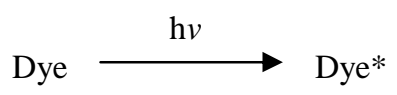

(3)

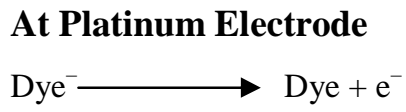

\subsection{Dark Chamber}

\section{At Calomel Electrode}

Dye $+\mathrm{e}^{-} \longrightarrow$ Dye (Leuco)

$\mathrm{Dye}^{-}+\mathrm{R}^{+} \longrightarrow \mathrm{Dye}^{+}$

Where Dye, Dye*, Dye ${ }^{-}, \mathrm{R}$ and $\mathrm{R}^{+}$are the dye, excited form of dye, semi or leuco form of dye, reductant and oxidized form of the reductant, respectively. The process of mechanism in photogalvanic cell is represented in Figure 6. 


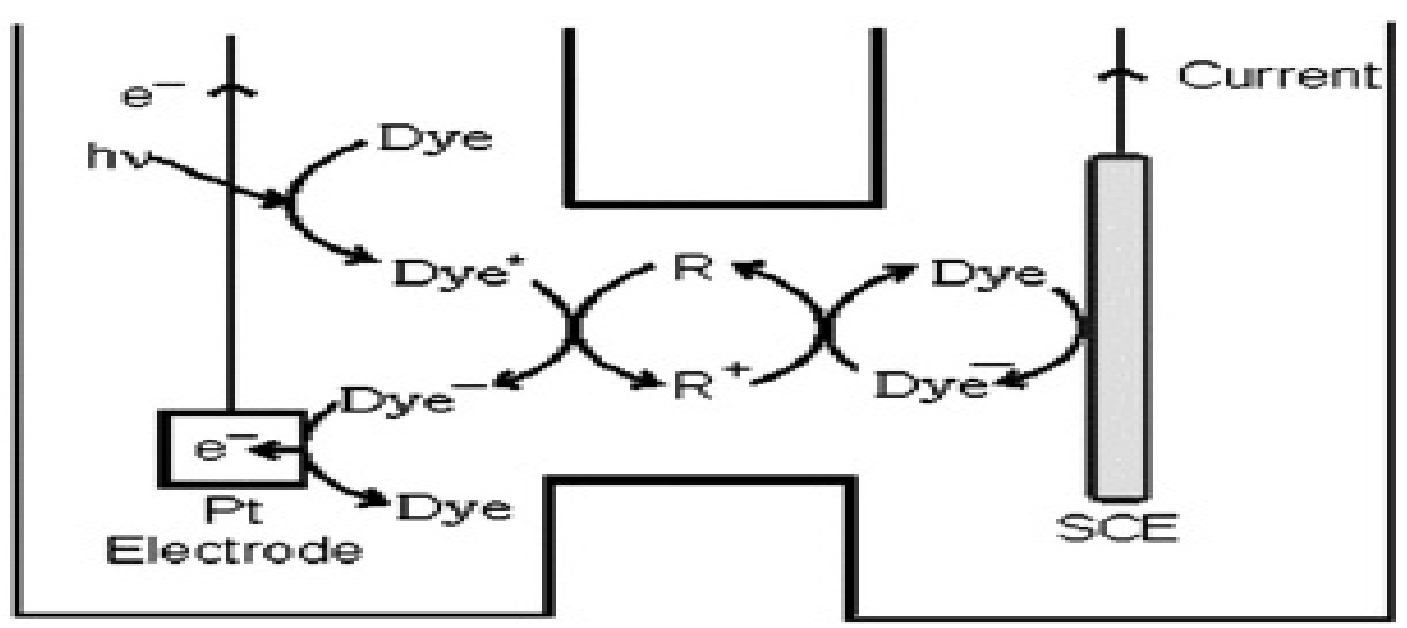

Fig-6 Processes of mechanism in photogalvanic cell

\section{CONCLUSIONS}

On the basis of the results, it is concluded that Methylene blue can be used successfully as heterocyclic dye with reductant and micelles in a photogalvanic cell. In the cell of Methylene blue-EDTA-TX 100 the observations are also taken with simple H-cell (without filter) the conversion efficiency and storage capacity of the cell is $1.087 \%$ and 160 minutes respectively on irradiation for 130.0 minutes developed photogalvanic cell. It has been observed that the hetrocyclic dye with reductant and micelles have not only enhanced the electrical parameters but also increased the conversion efficiency and storage capacity (performance) of the photogalvanic cell. Photogalvanic cells have better storage capacity than photovoltaic cells. So the photogalvanic cells can be used in dark whereas photovoltaic cell cannot be used in dark. Thus, photogalvanic cells showed good prospects of becoming commercially viable.

\section{NOMENCLATURE}

$\begin{array}{ll}\mathrm{i}_{\mathrm{eq}} & =\text { photocurrent at equilibrium } \\ \mathrm{i}_{\mathrm{max}} & =\text { maximum photocurrent } \\ \mathrm{i}_{\mathrm{pp}} & =\text { photocurrent at power point } \\ \mathrm{i}_{\mathrm{sc}} & =\text { short circuit current } \\ \mathrm{ml} & =\text { milliliter } \\ \mathrm{mV} & =\text { millivolt } \\ \mathrm{M} & =\text { molarity } \\ \mathrm{pp} & =\text { power point } \\ \mathrm{t}_{1 / 2} & =\text { storage capacity of cell } \\ \mathrm{DV} & =\text { observed photopotential } \\ \mathrm{V}_{\mathrm{oc}} & =\text { open circuit voltage } \\ \mathrm{V}_{\mathrm{pp}} & =\text { photopotential at power point } \\ \eta & =\text { fill factor } \\ \mathrm{mA} & =\text { microampere } \\ \mathrm{mW} & =\text { microwatt }\end{array}$

\begin{tabular}{|llc|}
\hline S.NO & Parameter & Observed Value \\
\hline 1 & Dark potential & $237.0 \mathrm{mV}$ \\
\hline 2 & Open circuit voltage $\left(\mathrm{V}_{\mathrm{OC}}\right)$ & $1082.0 \mathrm{mV}$ \\
\hline 3 & Photopotential $(\mathrm{DV})$ & $845.0 \mathrm{mV}$ \\
\hline 4 & Equilibrium photocurrent $(\mathrm{ieq})$ & $420.0 \mathrm{~mA}$ \\
\hline 5 & Maximum photocurrent $\left(\mathrm{i}_{\max }\right)$ & $490.0 \mathrm{~mA}$ \\
\hline 6 & Initial generation of photocurrent & $24.5 \mathrm{~mA} \mathrm{~min}$ \\
\hline 7 & Time of illumination & $130.0 \mathrm{~min}$ \\
\hline 8 & Storage capacity $\left(\mathrm{t}_{1 / 2}\right)$ & $160.0 \mathrm{~min}$ \\
\hline 9 & \% of storage capacity of cell & $1.2307 \%$ \\
\hline 10 & Conversion efficiency & $1.087 \%$ \\
\hline 11 & Fill factor $(\eta)$ & 0.2488 \\
\hline
\end{tabular}

[Methylene blue] $=2.04 \times 10^{-5} \mathrm{M}$; Light Intensity $=10.4 \mathrm{~mW}$ $\mathrm{cm}^{-2}$; [EDTA $]=1.20 \times 10^{-3} \mathrm{M}$; Temp. $=303 \mathrm{~K}$; [TX-100] $=$ $0.84 \times 10^{-3} \mathrm{M} ; \quad \mathrm{pH}=11.60$

\section{ACKNOWLEDGEMENTS}

The authors are thankful to The Head, Department of Chemistry, MLS University, Udaipur-313001, Rajasthan (INDIA). One of the authors (A.S. Meena) is grateful to The Ministry of New and Renewable Energy (MNRE), Government of India, New Delhi-110003 (INDIA) for providing the necessary laboratory facilities to conduct this research work.

\section{REFERENCES}

[1] Rideal E. K. and Williams E.G., J. Chemical Society Trans., 1925, 127, 258-269.

[2] Rabinowitch E., J. Chem. Phys., 1940, 8, 551-559.

[3] Rabinowitch E., J. Chem. Phys., 1940, 8, 560-566.

[4] Potter A.E. and Thaller L. H., Solar Energy, 1959, 3, 17.

[5] Wolf M., Proc. I. R. E., 1960, 48, 1246-1263. 
[6] Rohatgi- Mukherjee K.K., Roy M. and Bhowmik B.B., Solar Energy, 1983, 31, 417-418.

[7] Madhwani S., Vardia J., Punjabi P.B. and Sharma V.K., J. Power and Energy: Part A, 2007, 221, 33-39.

[8] Dixit N.S. and Mackay R.A., J. Phys. Chem., 1982, 86, 4593-4598.

[9] Kamat P.V., J. Chem. Soc., Faraday Trans., 1985, 1, 509-518.

[10] Peng W., Shaik M. Z., Pascal C., Raphael C., Humphry-Baker R., and Gratzel M., J. Phys. Chem. B, 2003, 107, 14336-14341.

[11] Albery W.J. and Archer M.D., Nature, 1977, 270, 399402.

[12] Ameta S.C., Khamesra S., Chittora A. K. and Gangotri K. M., Int. J. Energy Research, 1989, 13, 643-647.

[13] Gangotri K.M. and Regar O.P., Int. J. Energy Res., 1997, 21(14), 1345-1350.

[14] Gangotri, K. M., Lal, C., J. Power and Energy Part A, 2005, 219(A5), 315-320.

[15] Lal Chhagan, J. Power Sources, 2007, 164(2), 926930.

[16] Jana A.K. and Bhowmik B.B., J. Photochem. Photobio. A: Chem., 1999, 122, 53-56.

[17] Gangotri K.M. and Meena R. C., J. Photochem. Photobio. A. Chem., 2001, 141, 175-177.

[18] Madhwani S., Ameta R., Vardia J., Punjabi P.B. and Sharma V.K., Energy Sources, Part A, 2007, 29, 721729.

[19] Genwa K.R. and Khatri N.C., Int. J. Chemical Science, 2006, 4, 703-712.

[20] Genwa K.R., Kumar A. and Sonel A., Applied Energy, 2009, 86(9), 1431-1436.

[21] Genwa K.R. and Chouhan A., Res. J. Recent Sci., 2012, 1, 117-121.

[22] Gangotri K.M. and Indora V., Solar Energy, 2010, 84, 271-276.

[23] Gangotri K.M. and Bhimwal M.K., Int. J. Elect. Power \& Energy Systems, 2010, 10, 1106-1110.

[24] Gangotri K.M. and Bhimwal M. K., Energy Sources, Part A, 2011, 33, 2104-2112.

[25] Bhati K.K. and Gangotri K.M., Int. J. Elect. Power \& Energy Systems, 2011, 33, 155-158.

[26] Bhimwal M.K. and Gangotri K.M., Energy Sources, 2011, 36, 1324-1331.

[27] Chandra M. and Meena R.C., Res. J. Chem. Sci., 2011, 1(1), 63-69.

[28] Chandra M. and Meena R.C., Int. J. Chem. Sci., 2010, 8(3), 1447-1456.

[29] Chandra M., Singh A. and Meena R.C., Int. J. Physical Sciences, 2012, 7(42), 5642-5647. 